\title{
Diversity of Amphibians in the Eastern and Southern Parts of the Sinharaja Rain Forest
}

\author{
H.I.G.C. Kumara \\ V.A.M.P.K. Samarawikrama
}

\begin{abstract}
The Sinharaja forest reserve is one of the least disturbed and biologically unique tropical lowland rain forests in Sri Lanka with the eastern Sinharaja consisting of moist sub-montane forests providing habitat par excellence for amphibians. However, the diversity of amphibians in the eastern and southern sections of Sinharaja is inadequately researched. Hence, this research focuses on studying amphibian diversity in lowland rain forests and sub-montane forests in eastern and southern Sinharaja. This research is guided by Quantitative Deductive research methodology and 16 line transects and 16 quadrate samples are used for primary data collecting. Twenty-four amphibian species were identified, $22(92 \%)$ species of which are endemic to Sri Lanka. The amphibian species identified included 5 vulnerable species, 7 endangered species and 8 critically endangered species. The highest number of species, including endangered and critically endangered species were recorded in the sub-montane forests than in lowland rain forest. Major threats to the existence of amphibian species were issues related to biopiracy including loss of forest genetic resources and wildlife smuggling, illegal forest utilization practices, gem mining, illegal forest encroachments and unethical tourism practices. Thus, the Forest Department and other responsible authorities must attend to minimize the effects of these negative human impacts on these vulnerable areas in order to protect and conserve the diversity of sensitive amphibian species in their habitats.
\end{abstract}

Keywords: Amphibian species, Sinharaja forest reserve, Lowland rain forests, Sub-montane forests 


\section{Introduction}

The Sinharaja forest reserve, one of the least disturbed and biologically unique tropical lowland rain forests in Sri Lanka spans over 11187 hectares of land at the elevation range of $150-1170 \mathrm{~m}$ above the sea level and four districts namely, Galle, Matara, Rathnapura and Kalutara. Sinharaja, the last viable remnant of tropical lowland rainforests of the country with rich and complex diversity of flora and fauna provides habitats for a variety of animals and vegetation (Kumara, 2010) of which more than $60 \%$ of the trees are endemic to Sri Lanka (Kumara, 2016). A variety of mammal species are also seen in Sinharaja and $50 \%$ of these species are endemic. Within the Sinharaja forest, there are thousands of small streams of crystal cool freshwater making habitats for a variety of fishes, toads, and crabs, many of which are endemic species. Hence, as a biological unit, Sinharaja holds a prominent place in the island (De Zoysa \& Raheem, 1990).

Having special ecological positions to keep the balance of natural ecosystems, amphibian species are directly and indirectly contributing sustainability of ecosystems (Bomford et al, 2009; Atauri \& de Lucio, 2001; Nijman \& Shepherd, 2011; Blaustein et al, 2011). Rain forest ecosystems in the world provide habitats to amphibian and facilitate their population dynamic and diversity (Raxworthy \& Nussbaum, 1994; Gehring Ratsoavina \& Vences, 2010), however, amphibian species are threatened with extinction due to the current trend of degradation of rain forests in the world (Reider, 2013). Thus, conservation of amphibian diversity and their habitats is an important global need.

Rainforest ecosystems of Sri Lanka provide important habitats for many rare and endemic amphibian species (Kudavidanage et al, 2012). Some studies are reported on their diversity, behavioral patterns, and ecological role. According to Meegaskumbura et all (2002), Sri Lanka can be identified a hotspot for amphibians since it was historically together with Western Ghats of India which has been declared a special hotspot for amphibians. Nevertheless, amphibian diversity in the island has been threatened since the country has almost lost more than $95 \%$ of its rain forest habitats from the last century. According to Pethiyagoda \& Manamendra-Arachchi (1998) more than 250 amphibian species have been reported within the island and most of them inhabit in rain forest areas of the country. Thus, rain forests of Sri Lanka provide ideal habitats for numerous amphibian species supporting high diversity.

According to Bambaradeniya et al. (2003), 33 amphibian species inhabit Sinharaja and 23 species are endemic to the island. Among the amphibians inhabiting this rain forest, 24 species were identified as nationally threatened species (Bambaradeniya et al., 2003). Many researchers have paid attention to study about diversity, potential threats and conservation needs of amphibian of the Sinharaja after 1990s (Ishwaran, \& Erdelen, 1990; Bambaradeniya et al., 2003; Surasinghe, 2007; Surasinghe \& Jayaratne, 2010). However, most of these studies were carried out in the northern section of Sinharaja and a few studies were based on the eastern section of Sinharaja. According to Jansen \& Bopage (2011), the 
eastern section of the forest is characterized by different biological, geographical and environmental features compared to the northern section of the forest. This area has been identified exceptional to Sri Lanka because of its high occurrence of endemic amphibian species.

When the existing knowledge about amphibian species of Sinharaja is examined, it is evident that studies on the amphibians in the southern and eastern parts of the forest are insufficient. However, the southern and eastern parts of the Sinharaja are reported to be biologically, geographically, ecologically as well as environmentally different compared to other areas of the rain forest (pilot survey, 2017). Variety of habitats such as primary forests, secondary forests, degraded forests, ridge forests, scrublands, forest patches, marshlands and abandoned Chena cultivation lands can be seen in this area (see Figure 1). This study with three specific research objectives such as (1) to generate a database about amphibian species found in this area; (2) to categorize them to conservation groups: Endemic species [E], Vulnerable species [VU]', 'Nearly threatened species' [NT], 'Endangered species' [EN] and 'Critically Endangered' [CR]; and (3) to analyse the biological value, vulnerability and threats of amphibian species in these particular sites, examines the diversity of amphibian species in the southern and eastern parts of the Sinharaja rain forest.

\section{Methodology}

The Quantitative Deductive research methodology is adopted in this research (McCusker \& Gunaydin, 2015) and under this methodology, a number of research methods have been used to collect and analyse data.

\section{Identifying the Knowledge Gap and Research Objectives}

A literature survey and pilot survey have been conducted to identify the potential knowledge gap, research questions and objectives of this research. A total of 8 days from 19 to 26 December 2017 [10 hrs per day (during day and night)] were spent to identify the suitability of this area for the research.

\section{Research Methods}

A total of 30 days (12 hrs per day within day and night) have been spent on fieldwork during April and November 2018. Mainly, line transects $(100 \mathrm{~m} \times 2 \mathrm{~m})$ and quadrate sampling methods $(8 \mathrm{~m} \times 8 \mathrm{~m})$ have been used for primary data collection processes. Four quadrate samples and four line transects have been randomly taken from each of the different habitats namely primary forests, secondary forests, degraded forests, marshlands, ridge forests, scrublands, forest patches, and abandoned chena cultivation lands located in the lowland rain forest and sub-montane forests. Accordingly, there were 4 quadrate samples and 4 line transect samples from each of the following localities: lowland rain forests in Giguruwa-Kosmulla (GO1 \& GO2) and Pitadeniya (PO1 \& PO2), and sub-montane forests in 
Handapanella (HO1 \& HO2) and Morningside (MO1 \& MO2). Altogether, there were 16 quadrate samples and 16 line transects for sampling in the present study.

All microhabitats such as water bodies under rocks, logs and decaying vegetation, and trees and bushes have been considered while selecting sampling plots. All captured specimens have been examined carefully and recorded before being released at their capture site without injury. No specimens have been collected, transported or deposited at any location outside the forest, but released back to their natural habitats. The species were identified and confirmed using diagnostic keys given by Bambaradeniya (2003), Surasinghe (2007), Surasinghe \& Jayaratne (2010), Manamendra-Arachchi \& Pethiyagoda (2006), De Silva (2003), Bossuyt et al. (2004) and Meegaskumbura et al. (2002). Threat criteria were given according to the Biodiversity Secretariat of the Ministry of Environment, 2012 (The National Red List 2012 of Sri Lanka).

\section{Description of the research sites}

Two sites from lowland rain forests and two sites from sub-montane forests were selected (Figure 1).

\section{Lowland rain forest (A)}

Giguruwa- Kosmulla area [GO1 \& GO2]. (Section to the southwest of Sinharaja)

Giguruwa-Kosmulla area is located near Neluwa in Galle the district. Sub-ecosystems in the Kubaldola area $(\mathrm{GO} 1)$ and the Giguruwa ridge mountain area $(\mathrm{GO} 2)$ are used to collect samples.

Pitadeniya [PO1 \& PO2]. (Section to the south of Sinharaja)

Pitadeniya research site is located near Deniyaya in Matara district. A lowland forest area (PO 1) and ridge mountain site (PO 2) are used for the sampling.

\section{Sub-montane forest (B)}

Hadapanella [HO1 \& HO2] (Section to the eastern part of the Sinharaja)

Handapanella is in the eastern part of Sinharaja in the Ratnapura district near Rakvana. Sub-montane forest areas and marshlands and streamlines located within this site are used for data sampling.

Morningside [MO1 \& MO2] (Section to the eastern of Sinharaja)

Morningside is in the eastern part of the Sinharaja forest near the Suriyaknada area (between Deniyaya and Rakwana). Sub-montane habitants of this area are used to collect data in the research (Figure 1). 
Figure 1: Locations of the study area. G01 \& GO2: Giguruwa-Kosmulla (PO1 \& PO2), Pitadeniya, Hadapanella (HO: 1 \& 2), HO1 \& HO2: Hadapanella; MO1 \& MO2: Morningside.

(Map drawn by Prasanna Samarawikrama [Codes of sampling site are as given in map])
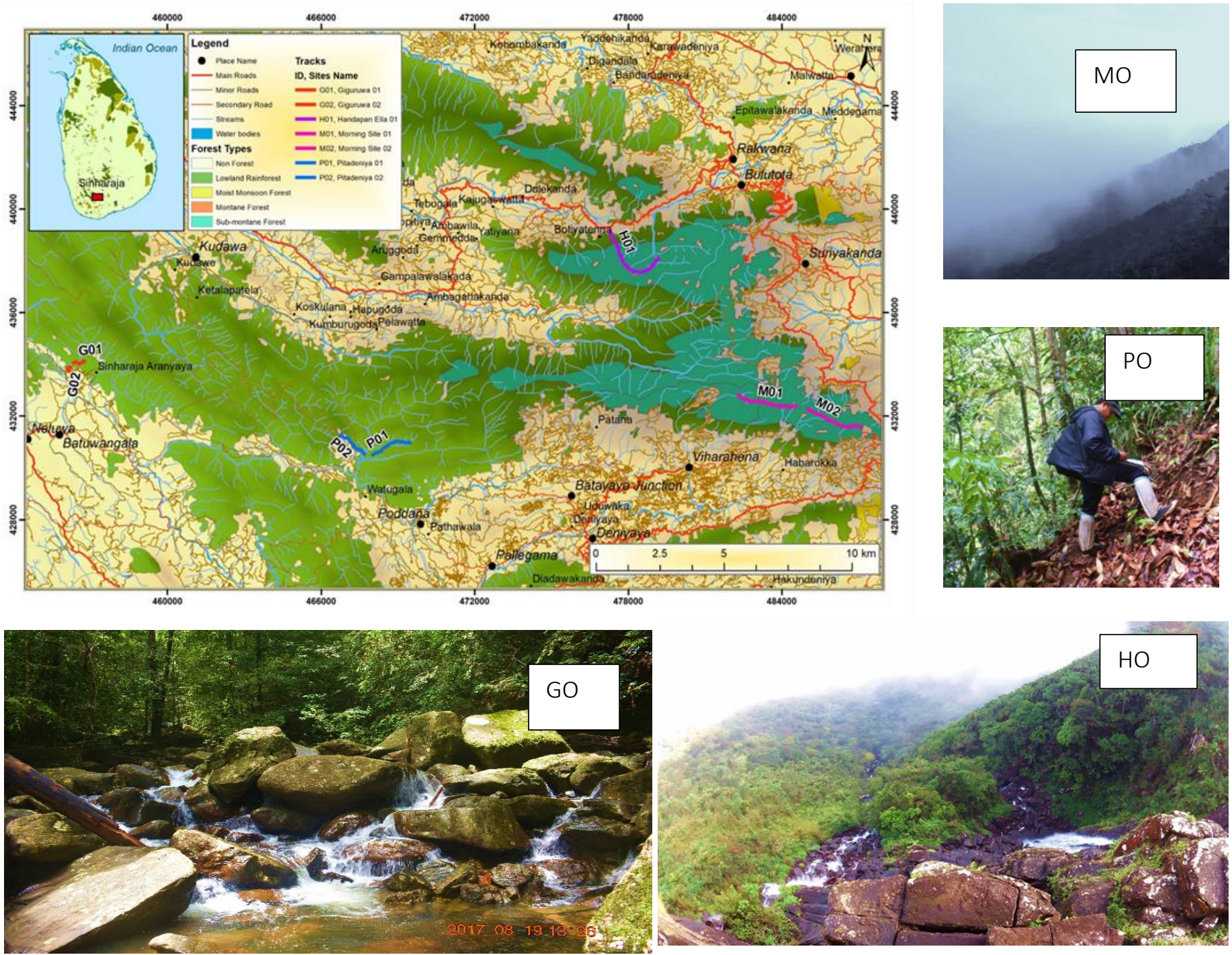
Figure 2: Diversity of Amphibians in the Eastern and Southern parts of the Sinharaja Rain Forest

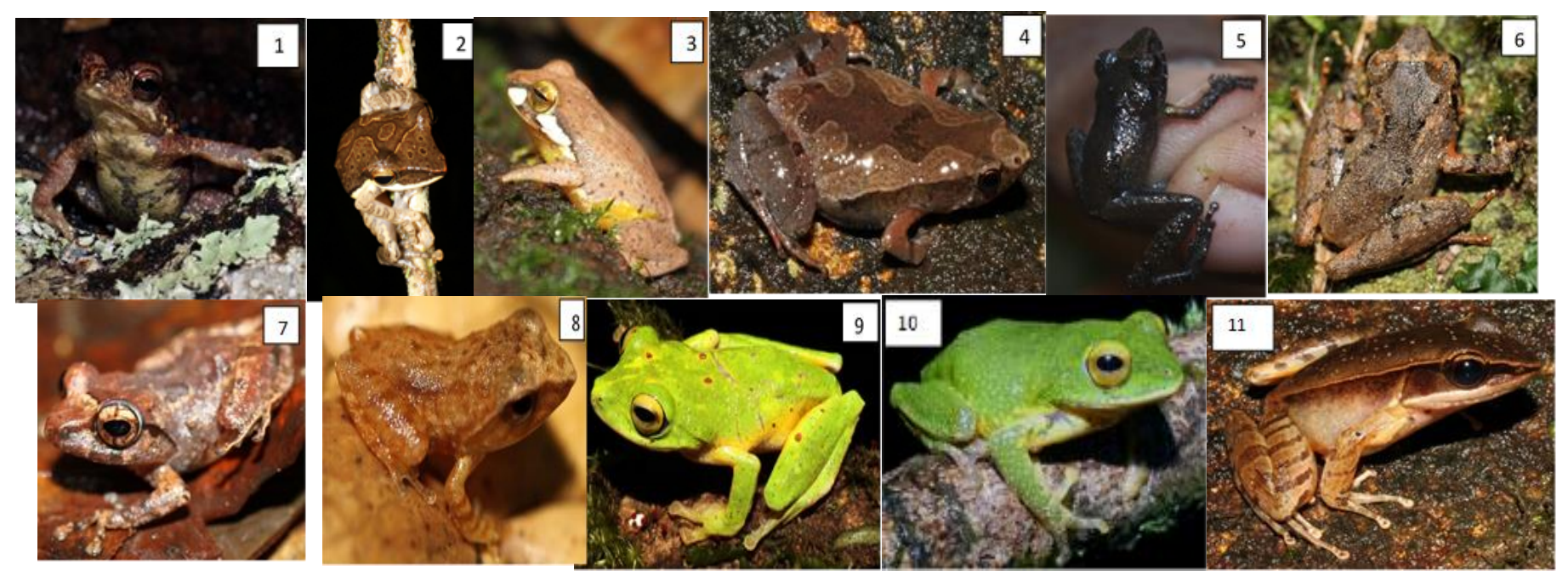

1. Adenomus kelaartii -VU, $\mathrm{E}$

3. Pseudophilautus hoipolloi -EN, E

5. Pseudophilautus nemus -CR, E

7. Pseudophilautus silvaticu $-\mathrm{EN}, \mathrm{E}$

9. Pseudophilautus poppiae- $\mathrm{CR}, \mathrm{E}$

11. Hylarana temporalis $-\mathrm{E}$
2. Polypedates fastigo $\mathrm{CR}, \mathrm{E}$

4. Microhyla karunaratnei -EN,

6. Pseudophilautus procax $\mathrm{CR}, \mathrm{E}$

8. Pseudophilautus auratus EN, E

10. Pseudophilautus acularis - EN, E

\section{Results and Discussion}

According to the findings, both the lowland rainforest and the sub-montane forests are identified as biologically sensitive and important sites for reptile diversity. There are 111 native amphibian species in Sri Lanka and 95 species are endemic to the island (Biodiversity Secretariat of the Ministry of Environment, 2012). In the study area, there were 24 species of which 22 (92\%) were endemic. Furthermore, when national conservation status was considered, of these amphibian species 5 were vulnerable, 7 were endangered and 8 were critically endangered. The highest number of species were recorded in the sub-montane forest, especially in the Morningside than in the lowland rainforest (In lowland rainforests: 9 species in Giguruwa-Kosmulla site and 10 species in Pitadeniya site; in the submontane forests: 11 species in the Handapanella site and 12 species in the Morningside site). The most vulnerable species are recorded in the lowland rainforests and the highest percentage of endemic, endangered and critically endangered species are recorded in the sub-montane forests (Table 1). 
Threats to amphibian species

Some issues were identified as main threats to amphibian habitats in both lowland rainforests and submontane forests. Currently, Wallapatta smuggling (Gyrinopswalla) has become a serious issue in Giguruwa-Kosmulla, Pitadeniya as well as the Handapanella sites and, it mainly contributes to accelerate the degradation of habitats of amphibian species (Kumara, 2016a; 2016b, 2017). During the field research, it was observed that people stayed in the forest at night for gathering forest materials, poaching and tree felling for timber. These types of forest utilization practices directly and negatively impact on amphibian habitats (Kumara, 2013). Four huts used to stay temporarily in the forest at night by people who utilize forest resources illegally were observed in the Giguruwa-Kosmulla site.

Illegal forest encroachment was observed in many areas, and especially, it was a serious issue in the Handapanella area. Forest ecosystems in the Handapanella area have been used for illegal gem mining which was also a threat to forest ecosystems. During the fieldwork in the Pitadeniya site, we observed irresponsible tourist behaviour, especially, behaviour of local tourists which negatively influenced on the ecosystems.

\section{Conclusion}

Both lowland rainforests and sub-montane forests can be considered as biologically sensitive habitats for amphibian species. However, a high number of amphibian species are recorded in sub-montane forests than in lowland rain forests. Twenty five amphibian species were identified during the present study and among them 22 (92\%) species were endemic to Sri Lanka. Among the amphibian species identified, 5 were vulnerable species, 7 were endangered species and 8 were critically endangered species. The highest number of species and also endangered and critically endangered species were recorded in the sub-montane forests, especially, in Morningside than in lowland rain forests. There are many threats to the ecosystem and issues of biopiracy, loss of forest genetic resources and wildlife smuggling, illegal forest utilization practices, gem mining, illegal forest encroachments and irresponsible tourism practices were major problems among them. Thus, the Forest Department and other responsible authorities must attend to minimize the impact of these possible threats to sensitive amphibian habitats to protect their biodiversity.

\section{Acknowledgement}

The authors would like to acknowledge the Small Grant Research Programme of the Ministry of Mahaweli Development \& Environment for financial assistance and the Forest Department and Wildlife Conservation Department for granting research permits to conduct this research. Thanks are also due to Ms. RAWD Jayawardhane, Mr. Damith Lakmal, Mr. D.H.G Rajapaksha, Mr. Manjula Lankanth and Mr. Prasanna Samarawikrama for their assistance in data analysis, and preparation of the map. 


\section{References}

Atauri, J. A., \& de Lucio, J. V. (2001). The role of landscape structure in species richness distribution of birds, amphibians, reptiles and lepidopterans in Mediterranean landscapes. Landscape Ecology, 16(2), 147-159.

Bossuyt, F., Meegaskumbura, M., Beenaerts, N., Gower, D. J., Pethiyagoda, R., Roelants, K., \& Ng, P. K. (2004). Local endemism within the Western Ghats-Sri Lanka biodiversity hotspot. Science, 306(5695), $479-481$.

Biodiversity Secretariat of the Ministry of Environment. (2012). The National Red List 2012 of Sri Lanka, the Biodiversity Secretariat of the Ministry of Environment in Collaboration with the National Herbarium, Department of National Botanic Gardens, Colombo.

Blaustein, A. R., Han, B. A., Relyea, R. A., Johnson, P. T., Buck, J. C., Gervasi, S. S., \& Kats, L. B. (2011). The complexity of amphibian population declines: understanding the role of cofactors in driving amphibian losses. Annals of the New York Academy of Sciences, 1223(1), 108-119.

Bomford, M., Kraus, F., Barry, S. C., \& Lawrence, E. (2009). Predicting establishment success for alien reptiles and amphibians: a role for climate matching. Biological Invasions, 11(3), 713.

De Silva, A. (2003). Amphibians of Sri Lanka. Colombo, Sri Lanka

De Zoysa, N., \& Raheem, R. (1990). Sinharaja, a rain forest in Sri Lanka. March for Conservation.

Deraniyagala, P. E. P., 1953. A Colored Atlas of some vertebrates from Ceylon, Tetrapod Reptilia. National Museums of Sri Lanka, Colombo, Vol. 02: 101.

Deraniyagala, P. E. P. (1955). A Colored Atlas of Some Vertebrates from Ceylon, Serpentoid Reptilia. National Museums of Sri Lanka, Colombo, Vol. 03:121.

Dodd, C. K. (1995). Amphibian populations in the Commonwealth of Independent states: current status and declines.

S. L. Kuz'min, \& M. M. Pikulik (Eds.). Pensoft Publishers.

Gehring, P. S., Ratsoavina, F. M., \& Vences, M. (2010). Filling the gaps-amphibian and reptile records from lowland rainforests in eastern Madagascar. Salamandra, 46(4), 214-234.

Hallam, A. (1974). Changing patterns of provinciality and diversity of fossil animals in relation to plate tectonics. Journal of Biogeography, 213-225.

Ishwaran, N., \& Erdelen, W. (1990). Conserving Sinharaja: An experiment in sustainable development in Sri Lanka. Ambio, 237-244.

Jansen, P., \& Bopage, M. (2011). The herpetofauna of a small and unprotected patch of tropical rainforest in Morningside, Sri Lanka. Amphibians and Reptiles Conservation, 5(2), 1-13.

Kudavidanage, E. P., Wanger, T. C., Alwis, C., Sanjeewa, S., \& Kotagama, S. W. (2012). Amphibian and butterfly diversity across a tropical land-use gradient in Sri Lanka; implications for conservation decision making. Animal Conservation, 15(3), 253-265.

Manamendra-Arachchi, K., \& Pethiyagoda, R. (2006). Amphibians of Sri Lanka. Colombo, Sri Lanka: Wildlife Heritage Trust.

McCusker, K., \& Gunaydin, S. (2015). Research using qualitative, quantitative or mixed methods and choice based on the research. Perfusion, 30(7), 537-542.

Meegaskumbura, M., Manamendra-Arachchi, K., Schneider, C. J., \& Pethiyagoda, R. (2007). New species amongst Sri Lanka's extinct shrub frogs (Amphibia: Rhacophoridae: Philautus). Zootaxa, 1397(1), 1-15.

Meegaskumbura, M., Bossuyt, F., Pethiyagoda, R., Manamendra-Arachchi, K., Bahir, M., Milinkovitch, M. C., \& Schneider, C. J. (2002). Sri Lanka: an amphibian hot spot. Science, 298(5592), 379-379.

Nijman, V., \& Shepherd, C. R. (2011). The role of Thailand in the international trade in CITES-listed live reptiles and amphibians.PloS one,6(3), e17825.

Pethiyagoda, R., \& Manamendra-Arachchi, K. (1998). Evaluating Sri Lanka's amphibian diversity. Occasional Papers of the Wildlife Heritage Trust, 2, 1-12.

Praschag, P., H. Stuckas, M. Packert, J. Maran and U. F. (2011). Mitochondrial DNA sequences suggest a revised taxonomy of Asian flapshell turtles (Lissemys SMITH, 1931) and the validity of previously unrecognized

taxa (Testudines: Trionychidae). Vertebrate Zoology, 61 (1): 147-160.

Raxworthy, C. J., \& Nussbaum, R. A. (1994). A rainforest survey of amphibians, reptiles and small mammals at Montagne d'Ambre, Madagascar. Biological Conservation, 69(1), 65-73.

Reider, K. E., Carson, W. P., \& Donnelly, M. A. (2013). Effects of collared peccary (Pecari tajacu) exclusion on leaf litter amphibians and reptiles in a Neotropical wet forest, Costa Rica. Biological Conservation, 163, $90-98$. 
Bambaradeniya, C. N., Samarawickrema, V. A. M. P. K., Perera, M. S. J., Kekulandala, L. D. C. B., B., Fernando, R. H. S. S., Samarawickrema, V. A. P., \& Perera, W. P. N. (2003). Composition of faunal species in the Sinharaja world heritage site in Sri Lanka The Sri Lanka Forester, 26, 21-40.

Surasinghe, T. D. (2007). Conservation overview of herpetofauna of Sinharaja man and biosphere reserve of Sri Lanka. ZOOS'PRINT JOURNAL, 22(1), 2535-2538.

Surasinghe, T., \& Jayaratne, R. (2010). Diversity, Threats and Conservation of Herpetofauna in and around the Eastern Sinharaja. Sabaragamuwa University Journal, 6(1).

Vogel, G. and David. P. (2006). On the taxonomy of the Xenochrophis piscator complex (Serpentes, Natricidae), In: Herpetologia Bonnensis II: Proceedings of the 13th Congress of the Societas Europaea Herpetologica, Vences, M., J. Köhler, T. Ziegler \& W. Böhme (eds.): 241-246.

Vogel, G, and Rooijen, J. V. (2011). A new species of Dendrelaphis (Serpentes: Colubridae) from the Western Ghats - India. Taprobanica, 3 (2): 77-86. 